\title{
Business Networks Associated with Sustainability of SMEs in Uganda
}

\author{
Donatus Mugisha Rulangaranga (Corresponding author) \\ Department of Management Science, Makerere University Business School, \\ P. O. Box 1337, Portbell Road, Nakawa, Kampala, Uganda
}

Tel: 256-700-783810Ｅ-mail: donatusmugisha2015@gmail.com

\begin{abstract}
Alain Vilard Ndi Isoh
Faculty of Business Management and Sustainability, ICT University, Cameroon

P. O. Box 526, Yaoundé, Cameroon
\end{abstract}

Tel: 237-71-808232Ｅ-mail: alainvilard.isoh@ictuniversity.org

\begin{abstract}
Mellan Basemera
Department of Business Administration, Makerere University Business School, P. O. Box 1337, Portbell Road, Nakawa, Kampala, Uganda
\end{abstract}

Tel: 256-775-550405Ｅ-mail: bridgetmellan2015@gmail.com

Received: June 3, 2020 Accepted: June 18, 2020 Published: July 1, 2020

doi:10.5296/bms.v11i1.17104 URL: https://doi.org/10.5296/bms.v11i1.17104

\begin{abstract}
This research was carried out with an intention of establishing association between business networks and sustainability of SMEs in Uganda. A total of 384 SMEs were sampled for this purpose. From each SME, one respondent was considered. This respondent was either the owner or the manager. Survey method with specific focus on the use of closed ended questionnaire was employed in the study. Based on the factor analysis conducted on the data
\end{abstract}


collected, three important components of business networks were established namely; quality of suppliers, operations of business associations and SACCOs as well as existence of loyal customers. To test the association, correlation and regression analyses were conducted. Results indicated that all components of business networks had significant association with SME sustainability in Uganda. Out of the three, quality of suppliers had the highest degree of association while operations of business associations and SACCOs had the lowest association. The same trend was reflected in the results from regression analysis with the exception of operations of business associations and SACCOs which did not have significant influence onto SME sustainability. Based on these results, it was concluded that quality of suppliers and existence of loyal customers had significant influence onto SME sustainability in Uganda. It was recommended that SMEs in Uganda need to focus on quality of suppliers as well as loyal customers in order to realize sustainability. These two types of business networks are therefore crucial to the sustainability of SMEs in Uganda. Though they did not have significant influence, business associations and SACCOs need not be ignored considering that they too had a significant association with SME sustainability.

Keywords: SME Sustainability, business networks, quality of suppliers, loyal customers, SACCOs, operations of business associations

\section{Introduction}

This study was carried out with an intention of establishing useful business networks for the sustainability of Small and Medium Enterprises (SMEs) in Uganda. The study was motivated by the need to sieve through the many business networks that are currently existent in Uganda and establish those that are key to the sustainability of operations of SMEs.

Business networks refer to linkages that businesses get engaged in with the intention of furthering their business activities as well as their business interests. They are most times composed of repetitive business activities that enable associations between related and or connected businesses (Öberg, 2019). Related businesses are those that deal in more or less related activities. For instance, a trader and a delivery agent are considered to be related considering that they are more or less dealing in the same thing - ensuring a buyer gets the goods bought. A financial institution and a trader on the other hand could be considered to be connected businesses considering the need for their co-existence without necessarily dealing in the same thing (Abbas, Raza, Nurunnabi, Minai, \& Bano, 2019). All these kinds of networks are necessary for sustainability of SMEs in Uganda. They are however those that are more critical than others.

In Uganda today, SMEs are connected to each other in one way or the other. There is a connection with suppliers and or service providers, connection in form of associations and clubs, connection with financial institutions such as SACCOs, banks and micro-finance institutions as well as connections with customers (clients). All these connections are relevant for business sustainability in Uganda. There are however some that are more relevant than 
others. It is basing on this that this research study was commissioned to establish the key business networks that are most relevant for sustainability of SMEs in Uganda.

\section{Literature review}

Business networks are interrelationships between businesses and business people that help to foster business transactions. This eventually helps to boost business growth. It is however not a guarantee that when there are business networks, then businesses will grow. Growth is relative and is likely to be realized when appropriate mix of ingredients in the business networks is realized (Mayanja, Ntayi, Munene, Kagaari, \& Waswa, 2019).

The most obvious business network that can guarantee growth in business is the network with clients. This network helps to ensure market availability (Collier, 2014). It is however affected by the stiff competition that exists in a market place. Business people therefore need to do more than simply knowing their customers. Strategies for customer retention need to be sought and improved from time to time. This helps to create loyal customers for a business that help to market that very business to new and potential customers (clients) (García, Lizcano, Ramos, \& Matos, 2019).

Considering the importance of loyal customers, every business needs to have them. Existence of competition however, makes it challenging to keep them for long. Customer care strategies may be considered but still customers get attracted to other entities and or service providers. This therefore means that there is need for constant innovation to be in place in order to realize the needed level of customer base amidst stiff competition (Cargill, 2018).

Having linkages with suppliers is another form of a business network similar to having loyal customers. The difference however is that the suppliers help to ensure presence of raw materials and or goods for resale in time. When these are available, cases of stock out are avoided in a business operation (Doh \& Kim, 2014). To a greater extent therefore, strong supplier relationships help to boost existence of loyal customers in a business. It is however not a guarantee that loyal customers will indeed be formed as a result of strong supplier relationships with an existing entity (Collier, 2014).

Another dimension to supplier relationships is about the benefits that a supplier derives from an entity. Basing on this benefit, there are possibilities that the relationship will be enhanced or it will be destroyed and become inexistent over time (Doh \& Kim, 2014). For instance, there is the aspect of timely payments for supplies that are advanced to an entrepreneur (a small and or medium business person). If a supplier has to always demand for payments, then there is a high likelihood that such an alliance won't exist for a long time. The same may be the case if an entrepreneur has had a history of receiving sub-standard materials (raw materials or finished goods) from a supplier (Son, Lee, Ha, \& Nam, 2019). It is therefore important for an entrepreneur to ensure that the supplier relationships are nourished and sustained for a long period of time (Paparoidamis, Katsikeas, \& Chumpitaz, 2019).

One way to ensure long term supplier relationships is for businesses and or business people 
organizing themselves into associations. Associations are referred to as groups of like-minded people with an intention of accomplishing a certain task (Mayanja, Ntayi, Munene, Kagaari, \& Waswa, 2019; OECD, 2019). The association could also be for marketing purposes. For instance, there could association of taxi drivers, association of musicians, association of maize farmers as well as association of school owners. All these associations help to bring together these different business people with an intention of enabling them share their experiences. Through this kind of sharing, solutions are formulated for the betterment of all association members. One of the benefits is to have voice for negotiating prices as well as lobbying for markets of products (Businge, 2017).

In Uganda for instance, there are a number of associations of small and medium business owners such as the club of women in business (Achan, 2019), Uganda Sugar manufacturers Association (Kanaabi, 2018), Uganda National Dairy Traders Association (Okanya, 2016) and even Uganda Flowers and Exporters Associations (East African Business Week, 2017). From the practical point of view therefore, businesses and business people in Uganda already have associations. They use these associations to enable them grow as business people. This further encourages the business people to continue supporting each other through the associations. Business associations are therefore important vehicles for business growth (Businge, 2017). They however need to be formerly instituted and recognized in order to support the members.

Savings schemes and or SACCOs (Savings and Credit Co-operative Organizations) are also forms of business associations that are in existence at grass-root level. Though these do not have to be limited to people of a given profession or location, there are some that are formed basing on such grounds (Begajo, 2018; Sebhatu, 2011). For instance the teachers' SACCOs in Uganda (Nantambi, 2019) as well as SACCO for army men under the Uganda Peoples Defense Forces (UPDF) (Kazibwe, 2019). There are also SACCOs that are formed at village levels and or district levels (The Independent, 2019). In whatever form and or basis, the main objective of a SACCO has always been pooling financial resources for purpose of lending out the same to the members. They can therefore be likened to business associations geared towards enhancing availability of financial resources to business people (Feather \& Meme, 2019).

Though emphasis is put onto lending, SACCOs can also be used for savings for both business people as well as individuals who do not have business mindset. The savings are the ones that are lent out to those that want to do business (Henock, 2019). Once managed well, this kind of association is considered to be a big boost to small and medium businesses especially considering the structural challenges that these businesses face. The condition of being managed well has however been a challenge to many SACCOs that are formed in developing countries like Uganda (Businge, 2017; Burlando \& Canidio, 2017).

Considering Uganda as an example, collapse of SACCOs has been reported for the last ten (10) years. Two key reasons are cited for every SACCO that collapses; incompetent leadership of SACCOs as well as the aspect of poverty. Poverty makes it difficult for 


\section{Macrothink}

members to save and yet they want to borrow from the same SACCO that does not have enough savings to give out as loans. This is augmented by the leadership challenge that is most times ceremonial with little or no competence to manage a SACCO. This way, most SACCOs collapse at a fast rate. This trend can however be reversed since the cause of the collapse is known (The Independent, 2019).

Basing on the status of SACCOs in developing countries therefore, it is important to appreciate that they are important business associations though without promising future prospects for businesses that may tend to rely on them. This however does not mean that the SACCOs should stop operating. It is important for them to continue operating while registering improvement on a periodic basis (Mushonga, Arun, \& Marwa, 2018).

Improvement and eventual effective performance of SACCOs coupled with other forms of business associations such as Uganda flowers and exporters association have a potential of boosting business activities in Uganda. This potential is further augmented by the presence of loyal customers and effective supplier relationships. Interaction of these different business networks is also important to consider when ascertaining their individual and or group effect. The environment in which they exist needs to also be taken into consideration as far their success as business networks is concerned.

\section{Hypothesis and Conceptual Framework}

Basing on the detailed review of literature, the following hypothesis were derived for testing in this research;

$$
\begin{aligned}
H_{1}= & \text { There is a relationship between quality of suppliers (service } \\
& \text { providers) and sustainability of SMEs in Uganda } \\
H_{2}= & \text { There is a relationship between operations of business } \\
& \text { associations and SACCOs and sustainability of SMEs in } \\
& \text { Uganda } \\
H_{3}= & \text { There is a relationship between existence of loyal customers and } \\
& \text { sustainability of SMEs in Uganda }
\end{aligned}
$$

Related to the hypotheses, a conceptual model was developed to reflect the hypotheses. This model indicates how the different variables are hypothesized to relate with one another. This is presented in Figure 1 below. 


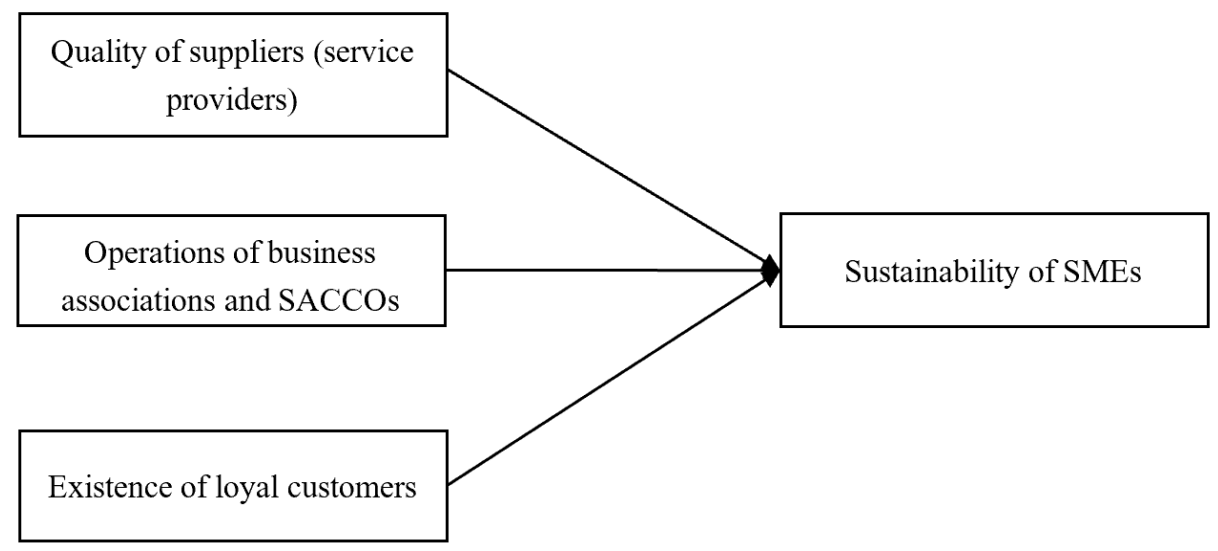

Figure 1. Conceptual framework

\section{Methodology}

This research was carried out following a cross sectional design with a bias on quantitative approaches. The focus on this design was based on the aspect of time spanning about one (1) year of operations of SMEs in Uganda. The need to test the variables and their interaction following quantitative approaches necessitated the design to be biased towards quantitative approaches.

The population was composed of the business owners and or managers. Their selection was however based on the number of SMEs they managed. This therefore means that the unit of analysis was an SME as represented by either a manager or owner of that SME. The SME also doubled as the sampling unit.

Considering the nature of SMEs in Uganda, there are many that get established in a year and others collapse during the same period. This phenomenon made it difficult to ascertain the exact number of SMEs existent in the country. They are however more than 1000 SMEs basing on information from Uganda Revenue Authority (URA) and Uganda Investment Authority (UIA). Basing on this, the population size was considered to be too large. Basing on this type of population, maximum sample size of 384 SMEs was selected. This was based on sampling formula advanced by Krejcie and Morgan (1970) which focuses on 95\% confidence interval, $5 \%$ error term and $50 \%$ population proportion. Cluster sampling technique was used.

Survey method was selected to collect data for this study. Specifically, a closed ended questionnaire form was used. The questions were formed based on a 5 point Likert scale to cater for the indifferent respondents.

The questionnaire was tested for reliability based on pilot study with a focus on realizing Cronbach's Alpha Coefficient of greater than or equal to 0.5. After completing the data collection exercise, the data collected was tested to check adherence to theory basing on which the hypotheses were derived. This was realized by carrying out Explanatory Factor 


\section{1l Macrothink}

Analysis, Cronbach's Alpha Test, Composite Reliability (CR) Test, Average Variance Extracted (AVE) and Confirmatory Factor Analysis (CFA).

The main analyses that were carried out to respond to the hypotheses were correlation and regression analyses. Correlation analysis was carried out to test the level of association of the variables in the hypotheses whereas the regression analysis was carried out to test the degree of influence of business networks on sustainability of SMEs in Uganda.

\section{Analysis and Findings}

Findings are presented in line with the research hypotheses. Before focusing on the hypotheses, presentation of Explanatory Factor Analysis (EFA) results, reliability analyses (Cronbach's Alpha and Composite Reliability) and Confirmatory Factor Analysis were made. These are explained in the subsections that follow.

\subsection{Explanatory Factor Analysis (EFA)}

In this analysis, the focus was to check the categorization of the question items in line with the latent variables. This categorization was done for quality of business networks as well as business sustainability for SMEs.

a) EFA Results for Quality of Business Networks

These are presented in Table 1 below.

Table 1. Quality of business networks - EFA output

\begin{tabular}{|c|c|c|c|}
\hline & \multicolumn{3}{|c|}{ Component } \\
\hline & 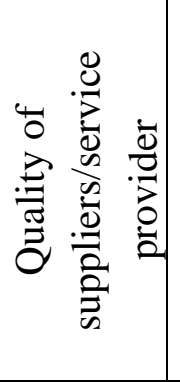 & 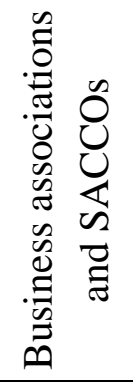 & 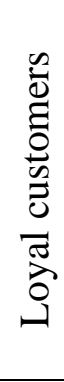 \\
\hline $\begin{array}{l}\text { I am satisfied with the products I receive from my } \\
\text { supplier }\end{array}$ & .811 & & \\
\hline My supplier gives me products at a discounted price & .780 & & \\
\hline $\begin{array}{l}\text { Even without supervision, my service provider gives me } \\
\text { a service that I am satisfied with }\end{array}$ & .716 & & \\
\hline My service provider/supplier respects my opinion & .691 & & \\
\hline
\end{tabular}




\begin{tabular}{|c|c|c|c|}
\hline $\begin{array}{l}\text { I have transacted with my current supplier/service } \\
\text { provider for more than three (3) years }\end{array}$ & .673 & & \\
\hline My organization has a business account with a SACCO & & .895 & \\
\hline My organization gets loans from a SACCO & & .886 & \\
\hline My organization is a member of a SACCO & & .871 & \\
\hline $\begin{array}{l}\text { Atleast one employee in my organization is a member of } \\
\text { an association (Eg: Association of drivers OR Uganda } \\
\text { National Farmers Associations etc) }\end{array}$ & & .640 & \\
\hline $\begin{array}{l}\text { My customers tell me when they are not satisfied with } \\
\text { what I give them }\end{array}$ & & & .735 \\
\hline $\begin{array}{l}\text { I receive ideas on how to improve my business from my } \\
\text { customers }\end{array}$ & & & .724 \\
\hline $\begin{array}{l}\text { In case my customers fail to get what they want from my } \\
\text { business, they promise to come back when it is available }\end{array}$ & & & .712 \\
\hline \% of Variance & 21.254 & 15.757 & 14.860 \\
\hline Cumulative \% & 21.254 & 37.011 & 51.871 \\
\hline
\end{tabular}

Extraction Method: Principal Component Analysis.

Rotation Method: Varimax with Kaiser Normalization.

Rotation converged in 8 iterations.

Information in Table 1 indicates that three main factors were extracted. These are quality of suppliers (service providers), operations of business associations and SACCOs as well as existence of loyal customers. This indicates that the three variables that were earlier generated were maintained. Though there are questions that had a factor loading less than 0.7 , they were accepted in this analysis because of passing the threshold of 0.4 which is acceptable in factor analysis (Samuels, 2017). Such factors are statistically considered to be stable. The cumulative percentage variance of $51.871 \%$ was obtained and considered to be good enough. 
b) EFA Results for SME sustainability

The results are presented in Table 2 below.

Table 2. EFA Results - SME sustainability

\begin{tabular}{|l|c|c|}
\hline Code of questions & Business size and profitability & Revenue performance \\
\hline E2_3 & .881 & \\
\hline E2_4 & .854 & \\
\hline E2_1 & .758 & \\
\hline E1_4 & .684 & .869 \\
\hline E1_3 & & .868 \\
\hline E1_1 & & .407 \\
\hline \% of Variance & $\mathbf{3 7 . 9 8 2}$ & $\mathbf{2 4 . 7 9 4}$ \\
\hline Cumulative \% & $\mathbf{3 7 . 9 8 2}$ & $\mathbf{6 2 . 7 7 6}$ \\
\hline
\end{tabular}

Extraction Method: Principal Component Analysis.

Rotation Method: Varimax with Kaiser Normalization.

Rotation converged in 3 iterations.

The EFA results of SME sustainability indicate that only two factors were extracted to explain SME sustainability. These were Business size and profitability as well as Revenue Performance. The same consideration provided by Samuels (2017) regarding factor loadings less than 0.7 was applied in the results in Table 2. This explains why a factor loading as low as 0.4 was considered in the EFA output in Table 2. A cumulative percentage variance of $62.776 \%$ was obtained from the analysis. Based on this, the output was accepted for consideration into further analysis. 


\subsection{Reliability and Validity Tests}

When testing for reliability of the extracted factors, three tests were conducted; Cronbach's Alpha Test, Composite Reliability (CR) Test and Average Variance Extracted (AVE). The results from these tests are provided in Table 3.

Table 3. Results from reliability and validity tests

\begin{tabular}{|l|c|c|c|}
\hline Variable & AVE & CR & CAC \\
\hline Quality of suppliers (service providers) & 0.542 & 0.855 & 0.811 \\
\hline Operations of business associations and SACCOs & 0.689 & 0.897 & 0.851 \\
\hline Existence of loyal customers & 0.523 & 0.767 & 0.690 \\
\hline Sustainability of SMEs & 0.603 & 0.911 & 0.801 \\
\hline Cut off point & $\mathbf{0 . 5 0 0}$ & $\mathbf{0 . 7 0 0}$ & $\mathbf{0 . 5 0 0}$ \\
\hline
\end{tabular}

Results in Table 3 indicate that all the variables had scores above the threshold. The results of AVE and CR indicate that all the four variables passed the convergent validity test. The reliability test results for all variable were also above the threshold of 0.5 . These test results indicate that the tools used were reliable and the questions were valid. To further confirm the results of EFA, a Confirmatory Factor Analysis (CFA) was conducted.

\subsection{Confirmatory Factor Analysis (CFA)}

This was conducted in order to confirm the results of EFA. It was conducted for both, quality of business networks as well as SME sustainability.

a) CFA output for Quality of Business Networks

This was conducted for a construct of "Quality of Business Networks" which is composed of three variables namely "Quality of suppliers", "Operations of business associations and SACCOs" as well as "Existence of loyal customers". The results from a CFA conducted are presented in Table 4 below.

Table 4. Results from CFA - Quality of Business Networks

\begin{tabular}{|l|c|}
\hline Measure & Statistic \\
\hline CMIN/DF & 3.505 \\
\hline GFI & 0.947 \\
\hline AGFI & 0.896 \\
\hline RMSEA & 0.089 \\
\hline
\end{tabular}




\section{Macrothink}

In line with the results presented in Table 4, the CFA model was developed. This is presented in Figure 2 below.

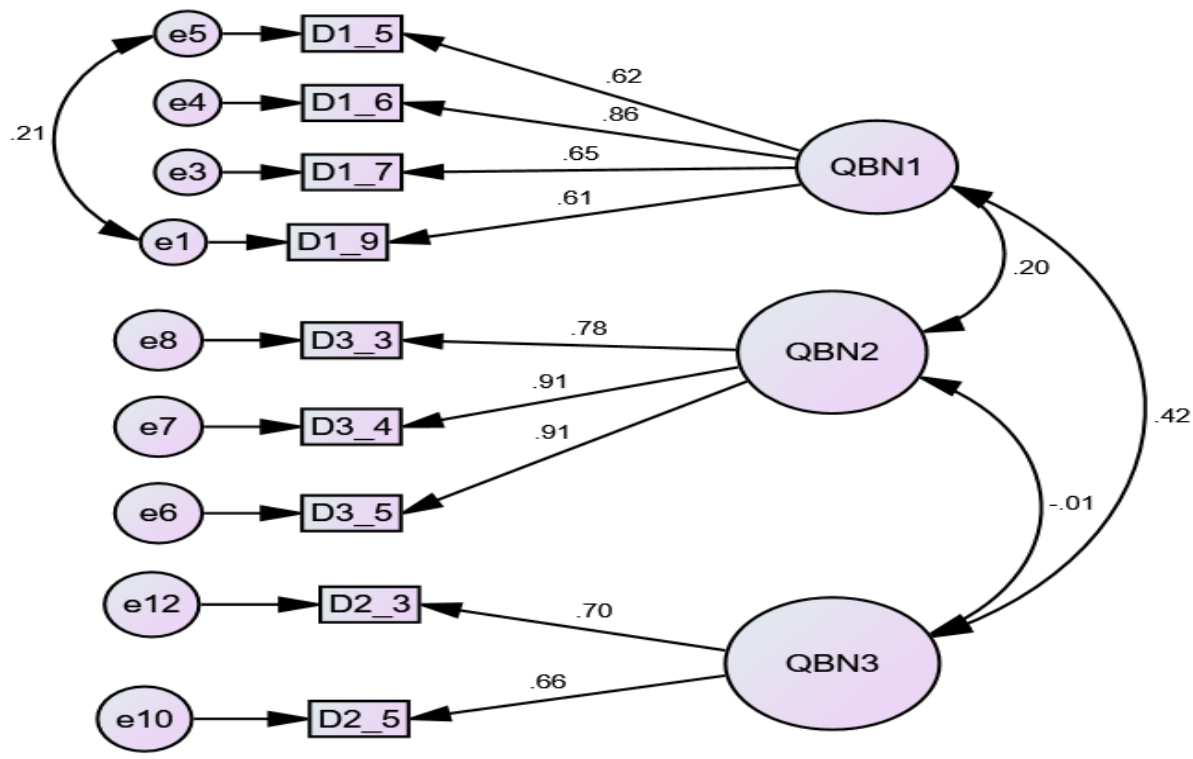

Figure 2. CFA Model Output for Quality of Business Network (QBN)

Meanings for the codes used in Figure 2 are provided in Table 5 below;

Table 5. Meaning to codes used in Figure 2

\begin{tabular}{|l|l|}
\hline Code & Meaning to code \\
\hline QBN1 & Quality of suppliers/service providers \\
\hline QBN2 & Business associations and SACCOs \\
\hline QBN3 & Loyal customers \\
\hline
\end{tabular}

b) CFA output for SME sustainability

Results from this analysis are presented in Table 6.

Table 6. Results from CFA - SME sustainability

\begin{tabular}{|l|c|}
\hline Measure & Statistic \\
\hline CMIN/DF & 1.619 \\
\hline GFI & 0.992 \\
\hline AGFI & 0.970 \\
\hline RMSEA & 0.044 \\
\hline
\end{tabular}




\section{Macrothink}

Business Management and Strategy

ISSN 2157-6068

2020, Vol. 11, No. 1

In line with the results in Table 6, a CFA model in Figure 3 was developed. This further indicates the items of SME sustainability that were retained after the CFA.

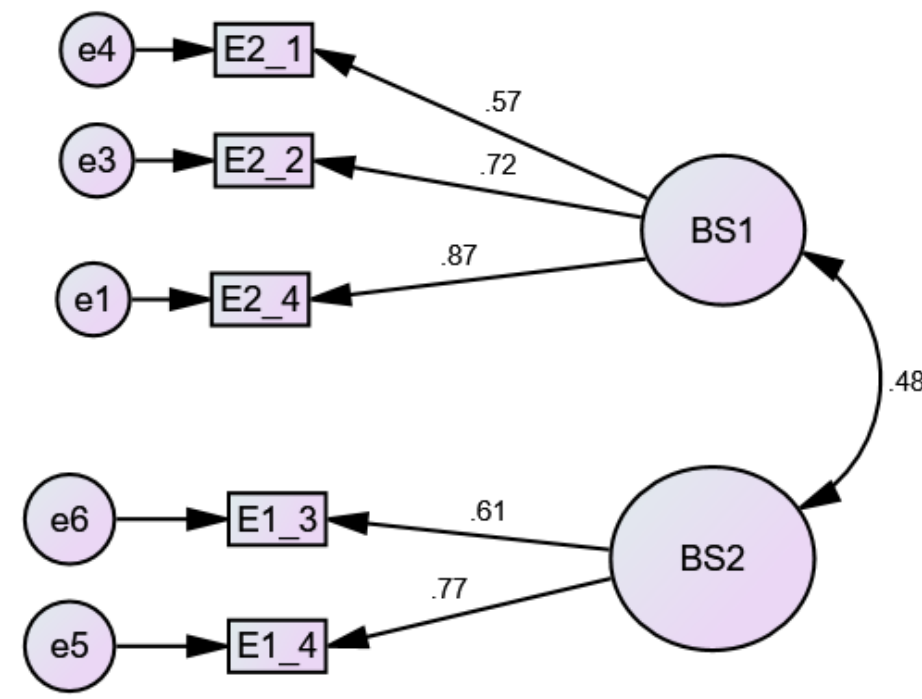

Figure 3. CFA Model Output for SME Sustainability

The CFA conducted indicates that some items were dropped and others were retained. In both cases (Figure 1 and Figure 2), items that had loadings below 0.5 were dropped. This was necessary to ensure a good model fit is realized for both variables.

When handling SME sustainability (Table 6 and Figure 3), two factors were extracted. Considering that SME sustainability was the dependent variable in this study, these two factors were aggregated into one variable after the confirmatory factor analysis (CFA). This variable was referred to as "Sustainability of SMEs".

\subsection{Correlation Analysis}

This analysis was carried out with an intention of establishing the level of association between the variables representing "Quality of Business Networks" and "Sustainability of SMEs in Uganda". Findings from this analysis are presented in Table 7.

Table 7. Correlation results

\begin{tabular}{|l|c|c|c|c|}
\hline & $\mathbf{1}$ & $\mathbf{2}$ & $\mathbf{3}$ & $\mathbf{4}$ \\
\hline Quality of suppliers/service providers (1) & 1 & & & \\
\hline Business associations and SACCOs (2) & $.173^{* *}$ & 1 & & \\
\hline Loyal customers (3) & $.219^{* *}$ & $.210^{* *}$ & 1 & \\
\hline Sustainability of SMEs (4) & $.396^{* *}$ & $.135^{*}$ & $.210^{* *}$ & 1 \\
\hline
\end{tabular}

**. Correlation is significant at the 0.01 level (2-tailed).

*. Correlation is significant at the 0.05 level (2-tailed). 


\section{Macrothink}

Business Management and Strategy

ISSN 2157-6068

2020, Vol. 11, No. 1

The findings in Table 7 indicate that all the three variables under Quality of Business Networks construct have a significant association with the level sustainability of SMEs in Uganda. Out of the three variables, the variable with the highest level of association with sustainability of SMEs was Quality of suppliers (service providers) $(\mathrm{r}=0.396 ; \mathrm{p} \leq 0.01)$. Next to this was "Existence of loyal customers" $(r=0.210 ; p \leq 0.01)$ and "Operations of business associations and SACCOs" $(r=0.135 ; \mathrm{p} \leq 0.05)$.

\subsection{Regression Analysis}

This analysis was carried out with an aim of establishing the degree of influence of "Quality of Business Networks" onto "Sustainability of SMEs" in Uganda. Deriving from the hypotheses set from the review of literature [Ref: Section 3.0], a model for consideration in the regression analysis was specified as indicated below.

Model specification - regression analysis;

$$
\begin{aligned}
& B S=f(Q S, B A, L C) \\
& B S=\alpha+\beta_{1} Q S+\beta_{2} B A+\beta_{3} L C+e \ldots \ldots \ldots \ldots \ldots \ldots \ldots \ldots \ldots . .1
\end{aligned}
$$

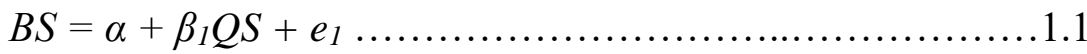

$$
\begin{aligned}
& B S=\alpha+\beta_{2} B A+e_{2} \ldots \ldots \ldots \ldots \ldots \ldots \ldots \ldots \ldots \ldots \ldots \ldots \ldots \ldots \ldots \ldots .2
\end{aligned}
$$

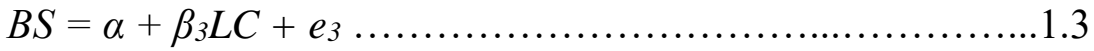

Where; [BS $\rightarrow$ SME Sustainability], [QS $\rightarrow$ Quality of suppliers], [BA $\rightarrow$ Business

Associations and SACCOs], [LC $\rightarrow$ Loyal Customers], $\left[e_{1}, e_{2}\right.$ and $e_{3} \rightarrow$ error terms for paths

(1), (2) and (3)] while $\left[\beta_{1}, \beta_{2}\right.$ and $\beta_{3} \rightarrow$ Path coefficients]. The priori expectation $\rightarrow \beta_{1}>$ $0 ; \beta_{2}>0 ; \beta_{3}>0$ as shown in Table 8:

\begin{tabular}{|c|c|c|c|c|}
\hline $\mathbf{N}$ & Variables & Measurement & Expected Impact & A priori \\
\hline & \multicolumn{4}{|l|}{ Dependent Variable } \\
\hline & $\begin{array}{l}\text { Sustainability of } \\
\text { SMEs (BS) }\end{array}$ & $\begin{array}{l}\text { Five point Likert Scale with } \\
\text { coding grading from } \\
\text { strongly disagree } \\
\text { strongly agree }\end{array}$ & & \\
\hline
\end{tabular}

Table 8. Measurement of variables and expected relationships 


\begin{tabular}{|c|c|c|c|c|}
\hline & \multicolumn{4}{|c|}{ Independent Variables } \\
\hline 1 & $\begin{array}{l}\text { Quality of } \\
\text { suppliers/service } \\
\text { providers (QS) }\end{array}$ & $\begin{array}{l}\text { Five point Likert Scale with } \\
\text { coding grading from } \\
\text { strongly disagree to } \\
\text { strongly agree }\end{array}$ & + & $\beta_{1}>0$ \\
\hline 2 & $\begin{array}{l}\text { Business } \\
\text { Associations and } \\
\text { SACCOs (BA) }\end{array}$ & $\begin{array}{l}\text { Five point Likert Scale with } \\
\text { coding grading from } \\
\text { strongly disagree to } \\
\text { strongly agree }\end{array}$ & + & $\beta_{2}>0$ \\
\hline 3 & $\begin{array}{l}\text { Loyal customers } \\
\text { (LC) }\end{array}$ & $\begin{array}{l}\text { Five point Likert Scale with } \\
\text { coding grading from } \\
\text { strongly disagree to } \\
\text { strongly agree }\end{array}$ & + & $\beta_{3}>0$ \\
\hline
\end{tabular}

Based on the model specification, a regression analysis was carried out. Findings of this analysis are presented in Table 9.

Table 9. Regression results

\begin{tabular}{|c|c|c|c|c|c|}
\hline & \multicolumn{2}{|c|}{$\begin{array}{l}\text { Unstandardized } \\
\text { Coefficients }\end{array}$} & \multirow{2}{*}{$\begin{array}{c}\text { Standardized } \\
\text { Coefficients }\end{array}$} & \multirow[t]{2}{*}{$\mathbf{t}$} & \multirow[t]{2}{*}{ Sig. } \\
\hline & B & S.E & & & \\
\hline (Constant) & 1.804 & .182 & & 9.895 & .000 \\
\hline $\begin{array}{l}\text { Quality of suppliers/service } \\
\text { providers }\end{array}$ & .336 & .050 & .359 & 6.753 & .000 \\
\hline $\begin{array}{l}\text { Business associations and } \\
\text { SACCOs }\end{array}$ & .035 & .037 & .051 & .958 & .339 \\
\hline Loyal customers & .086 & .035 & .132 & 2.467 & .014 \\
\hline
\end{tabular}

Dependent variable: Sustainability of SMEs

R: 0.423

R Square: 0.179

F: 22.511

Adjusted R Square: 0.171

Sig: 0.000 


\section{Al Macrothink}

The results indicate that "Quality of Business Networks" as a construct, has a significant influence onto the "level of sustainability of SMEs in Uganda (Modal Significance $=0.000$; $F$-statistics $=22.511 ; R$ Square $=0.179 ;$ Adjusted $R$ Square $=0.171)$. This finding indicates that the quality of business networks in Uganda influence up to $17.1 \%$ of the changes in the level of sustainability of SMEs. Though it is less than $50 \%$, it needs not to be ignored.

Focusing on the individual variables, the findings indicate that the most influential variable onto sustainability of SMEs in Uganda is Quality of suppliers (service providers) (Beta = 0.359; $\mathrm{Sig}=0.000)$. Next to this is the existence of loyal customers (Beta $=0.132$; $\mathrm{Sig}=$ 0.014). Operations of business associations and SACCOs were also found to have influence onto the level of sustainability of SMEs. This influence is however weak (Beta $=0.051)$ and not statistically significant $(\mathrm{Sig}=0.339)$.

\subsection{Summary of hypotheses accepted and rejected}

This is presented in Table 10 .

Table 10. Results from hypothesis testing

\begin{tabular}{|l|l|}
\hline Hypothesis & Decision \\
\hline $\begin{array}{l}\mathrm{H}_{1}: \text { There is a relationship between quality of suppliers (service } \\
\text { providers) and sustainability of SMEs in Uganda }\end{array}$ & Accepted \\
\hline $\begin{array}{l}\mathrm{H}_{2}: \text { There is a relationship between operations of business associations } \\
\text { and SACCOs and sustainability of SMEs in Uganda }\end{array}$ & Rejected \\
\hline $\begin{array}{l}\mathrm{H}_{3}: \text { There is a relationship between existence of loyal customers and } \\
\text { sustainability of SMEs in Uganda }\end{array}$ & Accepted \\
\hline
\end{tabular}

\section{Discussions, Conclusion and Recommendations}

The findings indicate that the most influential form of business networks that is in the operations of SMEs leading to their enhanced sustainability in Uganda is the quality of suppliers (service providers). The more qualified these suppliers (service providers) are, the more they get to enhance the level of sustainability of SMEs in Uganda.

This quality could be in terms of the products supplied to SMEs, the quality of services offered, delivery time, level of trust and or honesty on the side of suppliers (services providers) as well as the level of respect that these suppliers (service providers) accord to the managers and owners of SMEs (Paparoidamis, Katsikeas, \& Chumpitaz, 2019). This is an important aspect of business networks that happens on a daily basis in the operations of SMEs in Uganda. 
The importance of quality of suppliers (service providers) towards SMEs in Uganda is also supported by the literature. Businesses, big and small alike, treasure their source of goods and or services. Since this is what they directly trade on, they put a lot of value to it (Rajić, Nikolić, \& Milošević, 2016). It is this value that brings about the enhanced sustainability. This further means that, if there is need for the level of sustainability of SMEs to be enhanced, then the quality of suppliers and service providers in Uganda needs to be boosted.

Related to quality of suppliers (service providers) is the loyalty of customers (clients). No business exists without a customer (client). Customers may be loyal or disloyal. The focus on this finding is the existence of loyal customers. The findings indicate that existence of loyal customers in the operations of SMEs has a significant influence onto the level of sustainability of SMEs in the country.

Loyal customers could be categorized as customers who are true to a business person. They create a relationship which lasts a long period of time. Such customers, go an extra mile to help a business person improve his/her products and or services. This is always through provision of guidance and feedback about the products traded or services offered (Fourie, 2015). It is through this that an SME gets to advance in its operations (Paparoidamis, Katsikeas, \& Chumpitaz, 2019; Cargill, 2018). This therefore supports the findings obtained indicating that existence of loyal customers has a significant influence onto the level of sustainability of SMEs in the country.

Considering the findings about loyal customers, it is imperative to recommend that SME owners and managers need to work hard on creating loyal customers in their operations. One way this can be made possible is to get to understand the customers that visit and trade with an SME. This way, the customers that are willing to offer support as well as those that feel the value to be associated with an SME will be identified. These loyal customers will help to enhance the overall sustainability levels of SMEs in Uganda.

In relation to business associations and SACCOs, the findings indicate existence of association between them (business associations and SACCOS) and level of sustainability of SMEs in Uganda. The association is however weak. The same is observed from the results of influence of business associations and SACCOs though the influence is both weak and statistically insignificant. This means that, managers and owners of SMEs in Uganda, value their business associations as well as SACCOs but not so much that the associations and SACCOs may have influence on the sustainability of the SMEs they lead and manage.

The findings concur with the literature which indicates that SACCOs in Uganda have unfavorable performance with little accountability and members wanting to borrow rather than save (The Independent, 2019; The Independent, 2020). The same is for other forms of associations such as clubs and associations of professionals. These are good for lobbying. They may be more pronounced for big corporations in Uganda. In the case of SMEs however, they are still weak and are likely to have very little influence onto the level of sustainability of the SMEs. 
Based on the findings therefore, it is recommended that SME owners and managers need to pay attention to all their business networks and check their quality from time to time. The most important business networks to pay attention to however should be the quality of suppliers (service provider) and the existence of loyal customers. The operations of business associations and SACCOs are also good to look into though in the current state of affairs for SMEs in Uganda, the operations of business associations and SACCOs may not be significantly helpful in the enhancement of sustainability of SMEs.

\section{References}

Abbas, J., Raza, S., Nurunnabi, M., Minai, M. S., \& Bano, S. (2019). The Impact of Entrepreneurial Business Networks on Firms' Performance Through a Mediating Role of Dynamic Capabilities. MDPI - Sustainability, 2 - 28. https://doi.org/10.3390/su11113006

Achan, J. (2019). Women in business and more awarded. Retrieved Sept 20, 2019, from New Vision: https://www.newvision.co.ug/new_vision/news/1496287/women-business-awarded

Begajo, T. M. (2018). The Role of Saving and Credit Cooperatives in Improving Rural Micro Financing: The Case of Bench Maji, Kaffa, Shaka Zones. World Journal of Business and Management, 30 - 50. https://doi.org/10.5296/wjbm.v4i2.13849

Burlando, A., \& Canidio, A. (2017). Does group inclusion hurt financial inclusion? Evidence from ultra-poor members of Ugandan savings groups. Journal of Development Economics, 24-48. https://doi.org/10.1016/j.jdeveco.2017.05.001

Businge, J. (2017). SMEs are Uganda's engine for growth. Retrieved Sept 10, 2019, from The Independent: https://www.independent.co.ug/profile-smes-ugandas-engine-growth/

Cargill, C. K. (2018). Here are four steps SMEs can take for long-term success. Retrieved Sept 15, 2019, from World Economic Forum: https://www.weforum.org/agenda/2018/11/here-are-four-steps-smes-should-take-for-long-ter m-success/

Collier, T. S. (2014). Five steps that create inclusive growth through SMEs. Retrieved Sep 05, 2019, from The broker online: http://www.thebrokeronline.eu/Blogs/Boosting-Employment-in-Small-and-Medium-Enterpris es/Five-steps-that-create-inclusive-growth-through-SMEs

Doh, S., \& Kim, B. (2014). Government support for SME innovations in the regional industries: The case of government financial support program in South Korea. Research Policy, Elsevier, 43(9), 1557-1569. https://doi.org/10.1016/j.respol.2014.05.001

East African Business Week. (2017). Uganda: Flower Exporters Set to Invest U.S.\$17.8 Million in Value. Retrieved Sept 20, 2019, from All Africa: https://allafrica.com/stories/201708140698.html

Feather, C., \& Meme, C. K. (2019). Strengthening housing finance in emerging markets: the 
savings and credit cooperative organisation (SACCO) model in Kenya. Housing Studies, 1485-1520. https://doi.org/10.1080/02673037.2019.1584663

Fourie, L. (2015). Customer satisfaction: A key to survival for SMEs? Problems and Perspectives in Management, 13(3), 181 - 188.

García, J. J., Lizcano, D., Ramos, C. M., \& Matos, N. (2019). Digital Marketing Actions That Achieve a Better Attraction and Loyalty of Users: An Analytical Study. Future Internet, 1 16.

Henock, M. S. (2019). Financial sustainability and outreach performance of saving and credit cooperatives: The case of Eastern Ethiopia. Asia Pacific Management Review, 24(1), 1-9. https://doi.org/10.1016/j.apmrv.2018.08.001

Kanaabi, M. (2018). Sugar industry set for major shakeup. Retrieved Sept 20, 2019, from New

Vision: https://www.newvision.co.ug/new_vision/news/1489725/sugar-industry-set-major-shakeup

Kazibwe, K. (2019). UPDF Sacco hits 271 billion asset base. Retrieved Sept 18, 2019, from Nile Post: https://nilepost.co.ug/2019/03/27/updf-sacco-hits-271-billion-asset-base/

Mayanja, S., Ntayi, J. M., Munene, J. C., Kagaari, J. R., \& Waswa, B. (2019). Ecologies of innovation among small and medium enterprises in Uganda as a mediator of entrepreneurial networking and opportunity exploitation. Cogent Business \& Management. https://doi.org/10.1080/23311975.2019.1641256

Mushonga, M., Arun, T. G., \& Marwa, N. W. (2018). Drivers, inhibitors and the future of co-operative financial institutions: A Delphi study on South African perspective. Technological Forecasting and Social Change, 133, 254-268. https://doi.org/10.1016/j.techfore.2018.04.028

Nantambi, A. (2019). Gov't injects sh1.3b in national teachers SACCO. Retrieved Sept 18, 2019, from New Vision: https://www.newvision.co.ug/new_vision/news/1502394/gov-injects-sh13b-national-teachers -sacco

Öberg, C. (2019). The role of business networks for innovation. Journal of innovation and knowledge, 124 - 128. https://doi.org/10.1016/j.jik.2017.10.001

OECD. (2019). OECD SME and Entrepreneurship Outlook 2019. Paris: OECD Publishing.

Okanya, A. (2016). Court lifts ban on unpacked Milk. Retrieved Sept 20, 2019, from New Vision:

https://www.newvision.co.ug/new_vision/news/1422778/court-lifts-ban-unpacked-milk

Paparoidamis, N. G., Katsikeas, C. S., \& Chumpitaz, R. (2019). The role of supplier performance in building customer trust and loyalty: A cross-country examination. Industrial Marketing Management, 78, 183-197. https://doi.org/10.1016/j.indmarman.2017.02.005 


\section{Macrothink}

Rajić, T., Nikolić, I., \& Milošević, I. (2016). The antecedents of SMEs' customer loyalty: Examining the role of service quality, satisfaction and trust. Industrija, 44(3). https://doi.org/10.5937/industrija44-10741

Samuels, P. (2017). Advice on Exploratory Factor Analysis. Centre for Academic Success.

Sebhatu, K. t. (2011). Management of Savings and Credit Cooperatives from the Perspective of Outreach and Sustainability: Evidence from Southern Tigrai of Ethiopia. Research Journal of Finance and Accounting, 2(7).

Son, B.-G., Lee, C.-H., Ha, B.-C., \& Nam, H. (2019). Investigating the fair treatment of suppliers and its trust fostering role and performance benefits. International Journal of Production Economics, 216, 54-66. https://doi.org/10.1016/j.ijpe.2019.04.009

The Independent. (2019). Collapse of 13 Saccos in Kamwenge worries authorities, residents. Retrieved Sept 18, 2019, from The Independent Magazine: https://www.independent.co.ug/collapse-of-13-saccos-in-kamwenge-worries-authorities-resid ents/

The Independent. (2020). Don't kill your SACCO, Kadaga tells muslim journalists. Retrieved from The Independent Magazine: https://www.independent.co.ug/dont-kill-your-sacco-kadaga-tells-muslim-journalists/

\section{Copyright}

Copyright for this article is retained by the author(s), with first publication rights granted to the journal.

This is an open-access article distributed under the terms and conditions of the Creative Commons Attribution license (http://creativecommons.org/licenses/by/4.0/). 